\title{
Climate Change as a Factor in the Development of Companies: Corporate Strategies and Guidelines for State Industrial Policy
}

\author{
N. E. Terent'ev* \\ Institute of Economic Forecasting, Russian Academy of Sciences, Moscow, Russia \\ *e-mail:ternico@mail.ru \\ Received January 14, 2021; revised April 19, 2021; accepted April 28, 2021
}

\begin{abstract}
In recent years, the problem of global climate change has become one of the significant challenges for ensuring the sustainability of the functioning and growth in the market value of the world's leading industrial companies. Based on the latest data, the article describes the scale and impact of climate change on the development of companies and also considers some corporate strategies for reducing climate risks and adapting to the consequences of climate change. It is shown that, acting as a significant factor in the financial losses of business, the growing climate change, at the same time, indirectly contribute to the acceleration of the environmentally oriented transformation of corporate management systems and technological modernization of production complexes, creating, in conjunction with other technological and production trends, new sources of long-term competitiveness and market value. The article presents the characteristics of the priorities in the state industrial policy in the context of climate change.
\end{abstract}

Keywords: company, climate change, climate-related risks, low-carbon technology, adaptation, green economy, green growth, sustainable development, modernization, corporate strategies

DOI: $10.1134 / \mathrm{S} 1075700721050130$

Climate change as a global challenge to the development of the world economy. The last decades have been marked by growing changes in the functioning of climate regimes manifested in a rise in the average global temperature of the atmosphere, an increase in precipitation, a reduction in the ice cover of the circumpolar territories, an increase in the frequency and scale of weather and climatic anomalies (floods, hurricanes, heat waves, droughts, etc.) and large-scale shifts in the modes of ecosystems' functioning. The totality of these processes, which has received the generalized name of global climate change in the scientific literature, in recent years has firmly entered the number of significant challenges to sustainability in the functioning of the world economy as a whole and its various levels, including national economies, industries, large companies, and cities.

According to the latest data from global monitoring, climate change processes continue to intensify. The average global temperature of surface atmosphere in 2020 was $1.2 \pm 0.1^{\circ} \mathrm{C}$ higher than the level of the socalled preindustrial period (i.e., 1850-1900 taken as a base) [1]. The years 2015-2019 became the warmest five-year period since the beginning of regular hydrometeorological monitoring: the average global temperature exceeded the corresponding values of the previous five-year period by $0.21 \pm 0.08^{\circ} \mathrm{C}[2, \mathrm{p}$. 6]. The concentration of greenhouse gases in the atmosphere is currently at record levels. The rate of sea level rise in 2014-2019 was approximately $5 \mathrm{~mm} / \mathrm{yr}$, compared with an average of $3.24 \mathrm{~mm} / \mathrm{yr}$ for the period 1993-2019, due to the accelerated melting of the Antarctic and Greenland ice sheets. The annual amount of ice loss in Antarctica increased from 40 Gt in 19791990 to $252 \mathrm{Gt}$ in 2009-2017, i.e., more than six times [2, pp. 10-11]. In 2019, the $\mathrm{CO}_{2}$ concentration reached $410.5 \pm 0.2$ parts per million ( $\mathrm{ppm}$ ) representing $148 \%$ of the preindustrial level [1]. Despite a shortterm reduction in current $\mathrm{CO}_{2}$ emissions caused by quarantine measures during the onset of the COVID19 pandemic ${ }^{1}$, the cumulative $\mathrm{CO}_{2}$ concentration continued to increase in 2020 [1].

The scale of the climate change observed and expected during the 21 st century suggests its being one of the most significant groups of risks to socioeconomic development in the world and in Russia. This is confirmed by the available quantitative estimates and forecasts of the impact made by climate change on long-term GDP growth rates. For example, according to the forecast model developed by experts from the Organization for Economic Cooperation and Development (OECD), for the range of expected tempera-

\footnotetext{
${ }^{1}$ According to preliminary estimates, at the beginning of April 2020 , the daily global $\mathrm{CO}_{2}$ emissions were reduced by $17 \%$ compared to the 2019 level, by more than half, due to the reduction in traffic flows; the maximum reductions in individual countries are estimated at $26 \%$ [3], and for 2020 as a whole, by about 7\% [4].
} 
ture increases from 1.5 to $4.5^{\circ} \mathrm{C}$, the annual volume of lost GDP growth until 2060 may amount to about $2 \mathrm{pp}$ (in the range from 1 to $3.3 \mathrm{pp}$ ) [5, p. 12]. The main factors of this influence are a decrease in labor productivity and other negative consequences for the health of the population ( $0.9 \mathrm{pp})$, as well as damage to agriculture (0.8 pp). At the same time, in 2040-2060, it is expected that damage to health will almost double, and for agriculture increase threefold [5, p. 58]. There is also a threat of a significant reduction in world GDP per capita, which, according to the results of one of the studies [6], may decrease by $15-25 \%$ for warming by $2.5-3^{\circ} \mathrm{C}$ and by $30 \%$ for warming by $4^{\circ} \mathrm{C}$ (compared to a hypothetical scenario of no further global warming); in turn, the authors of the study estimate the cumulative economic benefits of keeping the temperature rise within $1.5^{\circ} \mathrm{C}$ at 20 trillion US dollars [6].

Increase in corporate risks due to climate change. Climate change is becoming an increasingly important factor in the long-term development of companies, especially multinational companies, which carry out business operations and operate production and supply chains around the world. At the same time, climate change primarily act as a risk factor for the long-term market and financial stability of companies and the continuity of their business processes. For example, according to the results of a survey of 5050 CEOs from 100 world's countries conducted by the PwC consulting company in February-March 2021, climate change was indicated by $30 \%$ of surveyed CEOs as one of the most significant threats (in 2020 this figure was 24\%) [7, p. 7]. According to the data provided by CDP (a nonprofit organization that develops systems and standards for corporate reporting in the field of greenhouse gases) for 2018, the world's 215 largest companies, accounting for 16.95 trillion US dollars of market capitalization, estimate the total value of assets exposed to climate-related risks in the amount of 970 billion US dollars. Moreover, about half of this volume refers to the period of the next five years $[8$, p. 6].

One of the key methodological issues of analyzing the impact of climate change at company level is that they can, to a certain extent, affect all business processes and management systems in companies. Generalizing two types of impact (and the corresponding risk groups) can be distinguished, i.e., direct, associated with the consequences of climate-related changes in the natural environment, and indirect, associated with changes in the market environment (new regulation, shifts in consumer behavior, etc.) (for more details, see [9] $)^{2}$.

Direct consequences of climate change cover a wide range of natural processes, hydrological (floods, etc.) and meteorological (hurricanes, extreme tem-

\footnotetext{
${ }^{2}$ It should be noted that in scientific literature, the term "physical risks" is also used to denote direct risks (impact factors), and the term "transition risks" to a green, low-carbon economy is used to denote indirect ones (see, for example, [10]).
}

peratures, etc.) natural emergencies. By the nature of their manifestation, they can be subdivided into extreme (weather and climatic anomalies, natural disasters) and relatively gradual changes in ecosystems (primarily the processes of permafrost thawing, desertification, sea level rise, etc.). These phenomena inflict significant damage not only on economic activity, but also on other major components of national wealth: human capital (public health) and natural capital (degradation of ecosystems).

One of the major threats to public health, labor productivity, and the sustainability of business processes is the increased frequency of heat waves. According to the International Labor Organization (ILO), in 1995, heat wave losses in the world accounted for $1.4 \%$ of working hours, which led to an economic loss of 280 billion US dollars in PPP; according to the forecast, by 2030, the value of these losses will increase to $2.2 \%$, which will amount to 2.4 trillion US dollars [11, p. 26]. The scale of this kind of negative consequences in Russia manifested itself during a record heat wave in the summer of 2010, which led to serious financial damage in a number of industries, including the agro-industrial complex as a result of crop losses (according to the Ministry of Agriculture, the damage amounted to 41.8 billion rubles), industry incurred damage due to a decrease in labor productivity (during the peak of the heat it was up to $30-50 \%$ ) and a temporary suspension of production [9].

With regard to gradual shifts in ecosystem functioning modes, the cumulative global losses from such shifts can reach hundreds of billions of US dollars. For example, the cumulative losses of the world economy from the rise in sea level to 2100 can range from 2.6 trillion US dollars (approximately 30 billion dollars/year) to 6.5 trillion US dollars (159 billion US dollars/year) depending on the scenario [12, p. 7].

For Russia, a significant part of whose territory is located on permafrost, the problem of increasing damage from thawing of permafrost is extremely urgent. According to estimates, the cumulative damage from this factor only to buildings and structures located on permafrost soils over the period 2020-2050 can range from 420 billion rubles to 3.36 trillion rubles, depending on the development scenario for the housing sector [13].

Along with a significant increase in the expected corporate losses from the direct consequences of climate change in the foreseeable future, an even more significant impact on the strategies and development prospects of companies will be exerted by indirect consequences caused by changes in the market environment of companies, as a result of which environmental and climatic factors determined by externalities are gradually becoming an important element of strategic management. At the international level, this is promoted by two key documents adopted in 2015, i.e., the UN Sustainable Development Goals (SDGs) 
until 2030 and the Paris Agreement, which, along with other international agreements, set a general institutional framework for the transition of the world economy to sustainable development based on evolving environmental (including low-carbon) technologies and the corresponding modernization of industrial complexes and infrastructure.

Leading industrialized and many developing countries have adopted strategies for transition to green growth, i.e., such economic growth, which does not lead to further degradation of the natural environment, promotes an effective balance between economic growth, environmental and resource constraints of ecosystems, and the biosphere as a whole, as well as public interests. This brings about, on the one hand, tightening of economic policy, including the introduction of increased requirements for industrial enterprises to reduce greenhouse gas emissions, up to the introduction of carbon taxes, technological modernization of production (e.g., through the institutional mechanism of the best available technologies). On the other hand, such a policy (and often with direct financial support from the state) results in the active creation of new market segments and niches and in opening up of new opportunities for diversification of production.

It should be emphasized that these measures of state regulation are aimed at solving two fundamental problems. The first one is associated with the simulation of technological and structural shifts in the economy, leading to an increase in its energy and carbon productivity; reducing dependence on energy imports; stabilization and subsequent reduction of air pollution levels, which pose significant risks to public health. Over the period 1990-2015, the level of energy productivity (GDP/TOE) in the world has approximately doubled, in the OECD countries it increased 1.5 times, in the BRICS countries 1.7 times, and in Russia 1.4 times [14, p. 39] (for more details, see [15]). The other key task of the state policy in the field of ecology and climate is to ensure the competitiveness of the national economy and the use of environmental (including climate) regulation as a tool of competition. It is in this context that we should view, for example, the EU measures taken to introduce a cross-border carbon tax on imports of products, the main purpose of which is to protect domestic producers. Thus, compliance with environmental and climatic standards becomes one of the factors of access to promising markets.

No less significant changes are associated with an increase in the role played by environmental and climatic factors in making consumer decisions. Thus, according to the survey covering 7520 people in nine countries $^{3}, 42 \%$ have changed their consumption habits under the influence of environmental factors and

\footnotetext{
${ }^{3}$ United States, UK, Sweden, France, Germany, Netherlands, Italy, Spain, India.
}

another $37 \%$ may change them in the future. In addition, $53 \%$ of the respondents indicated that they began to use the products of lesser-known brands and manufacturers, which they consider environmentally and socially responsible $[16$, p. 7,19$]$. Among the environmentally friendly consumer habits, the respondents mentioned, in particular, the following: minimizing food waste ( $60 \%$ of respondents), using energy efficient devices (45\%), buying local/seasonal food (42\%), and using their own packaging (68\%) [16, p. 8]. At the same time, there is a significant gap between declared readiness or approval of environmentally friendly products and the respondents' actual purchase, which is usually due to the higher price of such products (for more details, see, e.g., [17]). Thus, progress in the mass adoption of environmentally sustainable consumption patterns depends to a large extent on the standard of living and growth in the well-being of the population.

Technological and structural transformations of companies in the conditions of climate change. The response from business to the intensified environmental and climate-related risks in recent years has been the active adoption of innovative technologies aimed at reducing the specific consumption of energy and other material resources in the industrial and infrastructure sectors, adoption of systems for analyzing and optimizing the consumption of natural resources, the volume of greenhouse gas emissions for all stages of production, including through the use of smart grids and other information technologies.

In a broader context, we observe an evolution of the management approaches adopted by companies to environmental and climatic problems, which consists in the increasingly complete inclusion of these factors in the systems of the companies' strategic planning and in making strategic decisions, from the choice of the geographical location for new production facilities to the standards of working conditions for employees. Specific management subsystems that integrate certain aspects of accounting for environmental and climatic factors include the following management subsystems: risk, quality, costs, reputation (brand), and competitiveness as well as areas such as innovation and development, internal control and audit systems, corporate social responsibility, interaction with stakeholders, etc. [18].

One of the components of these strategic transformations in world industrial companies is active development systems of green (sustainable) industrial production. This process includes the innovative environmentally oriented modernization of the production systems consisting of two key components: mitigation and adaptation. The first (mitigation) strategy is aimed at building innovative production systems that are focused on minimizing the consumption of natural resources and the magnitude of social and environmental damage, as well as the production of environ- 
Table 1. Directions of green modernization for industrial companies

\begin{tabular}{|c|c|c|}
\hline $\begin{array}{l}\text { Directions of green } \\
\text { modernization for a company }\end{array}$ & Characteristic & Long-term strategic targets \\
\hline $\begin{array}{l}\text { Improving the environmental } \\
\text { attributes of products }\end{array}$ & $\begin{array}{l}\text { Ensuring improvements in the environmental attri- } \\
\text { butes of products, development of new environmen- } \\
\text { tally friendly products }\end{array}$ & $\begin{array}{l}\text { Environmentally friendly prod- } \\
\text { ucts }\end{array}$ \\
\hline Minimizing emissions & $\begin{array}{l}\text { Installation of treatment facilities, introduction of } \\
\text { production technologies that minimize environmen- } \\
\text { tal pollution and harm to public health }\end{array}$ & $\begin{array}{l}\text { Environmentally friendly pro- } \\
\text { duction systems }\end{array}$ \\
\hline Decarbonization & $\begin{array}{l}\text { Reducing the carbon intensity of production through } \\
\text { improved energy efficiency and wider use of low-car- } \\
\text { bon energy sources (including nuclear) }\end{array}$ & $\begin{array}{l}\text { Carbon neutral production sys- } \\
\text { tems }\end{array}$ \\
\hline $\begin{array}{l}\text { Reducing energy and material } \\
\text { intensity }\end{array}$ & $\begin{array}{l}\text { Reduction of energy and resource losses, introduction } \\
\text { of new technologies, materials, production methods } \\
\text { (including additive and digital technologies) }\end{array}$ & Smart manufacturing \\
\hline Waste management & $\begin{array}{l}\text { Minimization of volumes and recycling of industrial } \\
\text { waste and MSW, creation of an infrastructure for the } \\
\text { disposal and recycling of out-of-service products }\end{array}$ & $\begin{array}{l}\text { Formation of circular production } \\
\text { systems (waste-free production) }\end{array}$ \\
\hline Socially oriented changes & $\begin{array}{l}\text { Minimization (refusal) of using child labor, improve- } \\
\text { ment of working conditions in production, etc. }\end{array}$ & $\begin{array}{l}\text { Human-centered socially } \\
\text { responsible production }\end{array}$ \\
\hline
\end{tabular}

Source. Compiled by the author.

mentally friendly products, if this is in line with the strategic interests of the company (Table 1). The adaptation direction provides for the development and implementation of strategies for ensuring the longterm sustainability and continuity of the company's production infrastructure (in particular, covering the entire supply chain through joint development of standards and procedures with suppliers). The considered interpretation of sustainable production is generally consistent with the paradigm of inclusive and sustainable industrial development elaborated by the United Nations Industrial Development Organization (UNIDO) [19-20].

At the same time, the sustainable (green) model of socioeconomic development, which is gradually being formed in the world, faces significant challenges, both of a practical and technological nature (including the rate of reduction of greenhouse gas emissions that are insufficient to meet the target indicators of the Paris Agreement), and methodological problems caused by the complexity of taking into account environmental restrictions and public interests when making business decisions, as well as conflicting interests, since the necessary progress can only be achieved with mutual coordination of changes at each level of the world economy.

It seems that the main problems at the global level are contradictions in the economic interests of various agents (states, corporations etc), the lack of a unified vision for the future economic system that would satisfy the interests of all major economic agents. Under these conditions, the ideas and principles of green economy are often distorted in favor of narrow commercial interests. The lack of a realistic image projecting the future of the green economy is also associated with the apparent lack of existing market mechanisms stimulating transforming corporate strategies, and modifying consumer behavior.

At the level of national economies and their individual sectors, there is an additionally arising problem of imbalance in socioeconomic development. The adoption of strict environmental legislation can undermine the sustainability and competitiveness of domestic producers, and the delay in the adoption of innovative green technologies creates the risk of losing the competitive advantages of their timely introduction and ousting Russian companies from the global (and, in the long term, domestic) markets. Even more fundamental is the problem of the lack of new indicators for measuring the quality of economic growth. The methodology employed so far and closely tied to the GDP indicator does not take into account many of the negative environmental and social consequences of unbalanced economic growth.

At the regional level, complex methodological problems are yet to be solved in order to provide full accounting of the impact made by industrial production on the environment and ecosystems of specific territories, and to assess due compensation of damage caused by economic activities to public health as well as the sustainability of the natural environment.

At the microeconomic level, a fundamental contradiction persists between the business orientation towards maximizing (short-term) profits and environ- 
mental and social development priorities that ensure an increase in business capitalization and the creation of public goods on time horizons that exceed the investment payback periods of many industries. Without changing the logic and principles of making investment and, more broadly, strategic decisions, the possibilities for more active participation of business in the green modernization of production, apparently, will remain limited.

Finally, at the individual level, corporate policies that use a wide range of advertising and marketing strategies to stimulate excess demand for goods and services are a serious obstacle to adoption of sustainable consumption models, which create corresponding consumption habits. In addition, environmentally sustainable consumption practices can often be inaccessible to the general population, especially in developing countries, due to low incomes, as well as to the lack of adequate infrastructure, hence hindering the choice of environmentally safer working conditions, place of residence, etc.

Thus, the development of a new green model of socioeconomic development is a long-term complex process that requires changes at all levels of the world economy, as well as significant development of technologies available for mass adoption, for social changes aimed at more fully taking into account the interests of society in social (ensuring sustainable employment and income levels, reducing extreme poverty, hunger, etc.) and ecological (preventing excessive degradation of the natural environment and reducing biodiversity loss, minimizing damage from climate change) areas. These problems can only be solved with the development of new social principles and economic tools based on them.

On guidelines of state industrial policy under climate change. With all the significance of the problems connected with internal technological and structural transformations of industrial companies, the implementation of successful strategies for reducing climate-related risks and adapting to climate change, especially in Russian conditions, is only possible with effective interaction between the state and business, building a long-term industrial policy that, firstly, should take into account the factor of climate change when working out strategies for the development of industries and interaction with major industrial companies; secondly, it should be consistent with longterm technological trends in the transition to green growth, reduction of carbon intensity, and the formation of innovative production systems that correspond to the conditions of the sixth technological set that is currently being formed in the world.

State industrial policy in the field of climate change should be aimed mainly at technological modernization, improving balance, and creating additional opportunities for the development of the domestic industry, which are provided by technological progress in the field of green technologies.

These include, first of all, overcoming (reducing) technological lag (and, as a consequence, lagging behind in terms of economic growth) not only from industrially developed, but also from many developing, countries. Thus, the average annual growth rate of the Russian economy over the past ten years amounted to mere $0.9 \%$, compared with $3 \%$ of the average annual growth in the world economy. As a result, "Russia showed the worst economic performance among countries (except Venezuela) with a high share of the raw materials sector in the structure of GDP" [21, p. 4]. If this negative trend persists, a further reduction in technological and economic potential creates a critical threat to national security associated with the finalization of Russia's economic specialization in global supply chains as a supplier of natural resources and qualified human capital. Thus, the priority task of strategic planning and, in particular, of the state industrial policy, should be the accelerated restoration of internal technological and economic potential as a pillar of the country's long-term development; working out a new model of economic growth focused on the balanced development of all sectors in the economy based on the domestic market and the introduction of innovative technologies; creation of an independent financial and investment center in Russia, focused, among other things, on financing industrial innovations and infrastructure sectors in order to increase the long-term competitiveness of the Russian economy and the quality of life of the country's population.

From these positions, the tasks and functions of industrial policy are significantly expanded and go beyond the definition established by the specialized Federal Law On Industrial Policy in the Russian Federation, in accordance with which industrial policy is considered as "a set of legal, economic, organizational, and other measures aimed at the development of the industrial potential of the Russian Federation, ensuring the output of competitive industrial products" [22]. It is more appropriate to speak of a structural and investment policy, which implies "a set of measures aimed at smoothing out the disproportions of a sectoral, technological, and spatial nature that impede interaction between sectors of the economy and are not eliminated by traditional market mechanisms, and which include a system of targeted actions aimed at developing mechanisms for financing investment in the main capital" [23, p. 10], including those based on targeted programs for the development of specific industries and types of economic activity.

Within the framework of such a comprehensive approach, the strategic role of the green factor in the development of individual industries, intersectoral relations and structural shifts is to be increased. At the same time, it should be emphasized that the formation 
of a green economy is a fundamental technological and socioeconomic macrotrend that should be taken into account and used in Russia to solve acute problems of modernizing industry and infrastructure, reducing levels of environmental pollution, and improving the quality of life of the country's population. This, however, does not mean that one should blindly copy the strategies and approaches of other countries without adapting them to the development peculiarities of the domestic economy and the priorities of ensuring its long-term competitiveness.

On the contrary, the priorities for the development of climate policy in Russia should take into account for the foreseeable future the preserved role of the fuel and energy complex as a backbone sector of the economy and export, as well as the richest mineral resource base, which is the key to the country's resource independence and its key strategic advantage. As rightly noted in [24, p. 47], "green technologies are not only and not so much alternative types of energy, but also the effective use and capitalization of Russia's natural advantages in the form of water, forest, and soil resources." Thus, the major priority is the accelerated modernization of the energy and mining sectors, including the introduction of digital and green technologies (for more details, see [25]), in particular, minimization of heat energy losses during its transmission in utility networks, as well as the number of pipeline accidents caused by man-made and natural factors. In addition, we believe that the green economy can make a significant contribution to the development of new approaches to spatial development, allowing to take into account the value of ecosystem services of territories (for example, forest lands) and create a system for monitoring the quality of the natural environment, promote the development of domestic, including ecological, tourism, etc.

A balanced industrial policy presupposes taking into account the risks of excessively tightened norms for environmental regulation of industrial production, including those caused by the need to fulfill Russia's obligations under the Paris Agreement on climate change. This agreement, while opening up certain opportunities for stimulating high-tech low-carbon industries, at the same time creates serious risks to the competitiveness of the domestic industry in the event of the adoption of a federal law on the regulation of greenhouse gas emissions, which provides, among other things, ways for limiting the volume of these emissions, which in fact directly limits the growth potential of industries. The calculations made by the Institute of Economic Forecasting, RAS, show that "The implementation of an 'aggressive' scenario for reducing net greenhouse gas emissions in Russia and the world (which implies a sharp reduction in hydrocarbon production, accelerated introduction of renewable energy and electric transport technologies, the introduction of a tax on greenhouse gas emissions, and a number of other 'low-carbon shock therapy' measures) turns out to be incompatible with sustainable economic growth" as it leads to a "loss of $1.8 \mathrm{pp}$ average annual GDP growth rate in the period up to $2050 " 4$.

Thus, climate change, becoming one of the key factors in the development of companies, involves both significant risks that require system-based management strategies, including adaptation, and new opportunities for developing markets, increasing the sustainability of business processes, and, most importantly, rethinking the strategic priorities of business and looking for sources of competitiveness and capitalization growth that are more responsive to environmental constraints and public interests. The success in working out a new paradigm for the development of companies as well as the effectiveness of the public industrial policy will largely determine both the severity of the growing environmental and climatic crisis and the scale of its consequences for the economy and society.

\section{FUNDING}

This work was supported by the Russian Foundation for Basic Research, project no. 18-00-00600 (18-00-00599).

\section{REFERENCES}

1. World Meteorological Organization, State of the Global Climate 2020, Apr. 8 (2021). https://public.wmo.int/en/our-mandate/climate/wmo-statement-state-of-global-climate. Accessed April 12, 2021.

2. World Meteorological Organization, The Global Climate in 2015-2019. WMO-No. 1249 (2020).

3. C. Le Quere et al., "Temporary reduction in daily global $\mathrm{CO}_{2}$ emissions during the COVID-19 forced confinement," Nat. Clim. Change 10, 647-653 (2020).

4. C. Le Quéré, G. P. Peters, P. Friedlingstein, et al., "Fossil $\mathrm{CO}_{2}$ emissions in the post-COVID-19 era," Nat. Clim. Change 11, 197-199 (2021).

5. The Economic Consequences of Climate Change (OECD Publishing, Paris, 2015).

6. M. Burke, W. M. Davis, and N. S. Diffenbaugh, "Large potential reduction in economic damages under UN mitigation targets," Nature 557, 549-553 (2018).

7. A Leadership Agenda to Take on Tomorrow. 24th Annual Global CEO Survey (PwC, 2021).

8. Major Risk or Rosy Opportunity? Are Companies Ready for Climate Change? CDP Climate Change Report (2019).

9. N. E. Terent'ev, "Climatic risks and 'green' technologies: New factors in the development of companies," in Scientific Works: Institute of National Economic Forecasting of the Russian Academy of Sciences (MAKS Press, Moscow, 2011), pp. 116-135.

10. E. Feyen, R. Utz, I. Zuccardi Huertas, O. Bogdan, and J. Moon, Macro-Financial Aspects of Climate Change.

\footnotetext{
${ }^{4}$ For more details on the characteristics of the scenarios used and the calculation results, see [26].
} 
Policy Research Working Paper No. 9109 (World Bank, Washington, DC, 2020).

11. Working on a Warmer Planet: The Impact of Heat Stress on Labour Productivity and Decent Work (Int. Lab. Org., Geneva, 2019).

12. O. Nishiura, N. Tamura, et al., "An assessment of global macroeconomic impacts caused by sea level rise using the framework of shared socioeconomic pathways and representative concentration pathways," Sustainability 12 (9), 3737 (2020).

13. B. N. Porfiriev, D. O. Eliseev, and D. A. Streletskiy, "Economic assessment of permafrost degradation effects on the housing sector in the Russian Arctic," Herald Russ. Acad. Sci. 91 (1), 17-25 (2021).

14. Green Growth Indicators 2017 (OECD Publishing, Paris, 2017).

15. N. E. Terent'ev, "'Green' economy and the challenges of innovative development," Uch. Zap. Mezhdunar. Bankovsk. Inst., No. 3, 107-130 (2019).

16. How Sustainability Is Fundamentally Changing Consumer Preferences (Capgemini Research Institute, 2020).

17. K. Vringer, H. Vollebergh, van D. Soest, van der E. Heijden, and F. Dietz, Sustainable Consumption Dilemmas. OECD Environment Working Paper No. 84 (OECD, 2015).

18. S. Engert, R. Rauter, and R. J. Baumgartner, "Exploring the integration of corporate sustainability into strategic management: A literature review," J. Cleaner Prod. 112, 2833-2850 (2016).
19. Industrial Development Report 2016. The Role of Technology and Innovation in Inclusive and Sustainable Industrial Development (UNIDO, Vienna, 2015).

20. Industrial Development Report 2018. Demand for Manufacturing: Driving Inclusive and Sustainable Industrial Development (UNIDO, Vienna, 2017).

21. B. N. Porfiriev, A. A. Shirov, M. N. Uzaykov, M. S. Gusev, and I. N. Shokin, "The main directions of socio-economic development of Russia in 20202024 and for the period up to 2035," Stud. Russ. Econ. Dev. 31 (3), 245-253 (2020).

22. Federal Law No. 488 of December 31, 2014 "On Industrial Policy in the Russian Federation." http://pravo.gov.ru/proxy/ips/?docbody $=\&$ nd $=102365303$.

23. Structural and Investment Policy for Ensuring the Economic Growth in Russia: Monograph, Ed. by V. V. Ivanter (Nauchn. Konsul't., Moscow, 2017).

24. B. N. Porfir'ev, A. A. Shirov, and A. Yu. Kolpakov, "Climate for people, not people for climate," Ekspert, Nos. 31-34, 44-47 (2020).

25. Modernization of Industry and Development of HighTech Manufacturing in the Context of "Green" Growth. Monograph, Ed. by B. N. Porfir'ev (Nauchn. Konsul't., Moscow, 2017).

26. B. N. Porfir'ev, A. A. Shirov, and A. Yu. Kolpakov, "Low-carbon development strategy: Prospects for Russia's economy," Mirovaya Ekon. Mezhdunar. Otnosheniya 64 (9), 15-25 (2020).

Translated by I. Pertsovskaya 